UDC 316.334.4:340.115.4

DOI: https://doi.org/10.21564/2075-7190.35.119621

Klimova G. P., Doctor of Philosophical Sciences, Professor

\title{
LEGAL MENTALITY AND LEGAL CULTURE: PROBLEMS OF INTERACTION
}

The article presents the main theoretical and methodological approaches to the analysis of the essence of legal culture. Particular attention paid to the disclosure of the specificity of the axiological context of this social phenomenon. The essence and structure of legal mentality have been considered. The correlation of legal mentality and legal culture also has been analyzed.

Keywords: culture, legal culture, legal values, functions of legal culture, mentality, legal mentality.

Actuality of the problem. Formation of a law-governed state and civil society can be accomplished, on the one hand, by improving legislation and public administration, and on the other hand, through the provision of a high level of legal culture of Ukrainian citizens and it is impossible to form the rule of law in society without mentioned factors.

Analysis of the recent sources and publications. Problems of legal culture are at the center of attention of renowned scholars. They are the subject of numerous discussions and scientific studies of such scholars as S. S. Alexeyev, V. D. Babkin, C. Backhouse, G. I. Balyuk, S. L. Blumenthal, S. V. Bobrovnik, A. Budnik, N. A. Bura, R. Colson, J. P. Dias, A. Diduck, J. Drolshammer, A. Durbach, S. Field, R. Freedman, V. V. Golovchenko, G. Helleringer, J. Hytonen, K. W. Junker, D. A. Kerimov, V. V. Kopeichikov, V. O. Kotyuk, A. F. Kryzhanovsky, M. Leiboff, N. Lemay-Hérbert, L. Lixinski, Ye. N. Lukashova, N. I. Matusov, Ye. V. Nazarenko, V. V. Oksamitny, M. P. Orzikh, N. Peleg, R. Provost, K. Purnhagen, H. Reece, V. M. Salnikov, C. Sharp, S. Šarčević, V. F. Sirenko, V. Ya. Taciy, H. M. Zellentin and others [1-19]. Despite the fact that the process of studying various problems of legal culture is currently being actively pursued, no one can say that they are exhausted: many aspects of it should be studied. This is directly related to the fact that the consideration of the legal culture is narrow-minded, and it does not allow us to disclose the meaning of this concept comprehensively.

In this regard, the article aims to provide a social and philosophical analysis of legal culture, to consider its relationship with legal mentality.

Presentation of the main material. The concept of legal culture is multifaceted. Therefore, various theoretical and methodological approaches are used for its 
analysis. Among them: subjective, activitively, anthropological, technological, qualitative, sociological, axiological, and others. So, according to the subjective approach used by such researchers as O. V. Lukasheva, Yu. A. Dmitriev, Z. D. Ivanov and others the legal culture is understood as certain degree of knowledge of legislation and respect for the rules of law. These authors, in our opinion, baselessly limit the concept of legal culture by the attitude of people to legal provisions, that is narrow the concept of legal culture. Such significant phenomena as legal status of the individual, legal behavior, and so on stay beyond the discussed concept. In fact, the legal provisions stay outside of the legal culture, as it is not about these provisions, but it's about the attitude to them. The consistent implementation of this approach concerning with the analysis of legal reality and leads to the identification of legal culture with legal awareness.

In accordance with the activity approach supported by M. B. Smolensky, Yu. I. Agieev, V. V. Eglitis, etc., the legal culture considered as law-making activity. It is understood as a process and the result of human creativity in the field of law. Because of it, other, not less important, kinds of legal activity excluded from legal culture, for example, law-enforcement activity or activity of citizens to improve their law-educational level, etc. So all types of reproduction activity excluded from legal culture.

Anthropological understanding of legal culture proceeds from the fact that culture embraces everything that distinguishes the human life and society from the existing nature, that are all sides of human being. Culture includes everything created by human and characterizes the historicity of his existence in the world. Based on this broad understanding of culture, it can be found quite broad definition of legal culture in the scientific literature. As example we can understand the legal culture as a system of materialized and ideal elements that belong to the law field and they reflected in the consciousness and behavior of people. This concept developed in the works of R. S. Mogilevsky, K. A. Moraleva, V. V. Orekhov and others.

Proceeding from the technological approach the legal culture understood as a set of techniques, procedures, norms that are historically changing and that characterize the level of legal activity achieved by society. The emphasis here is not on what is being done in the legal field, but on how it has been done. In the scientific literature this concept is sufficiently consistent and fruitfully developed by E. V. Agranovskaya, E. A. Zorchenko, S. N. Kozhevinckov, A. L. Likas and others. At the same time, it must be emphasized that the right psychological climate of society, public opinion, the value-legal guidelines of citizens, etc. stay outside of mentioned understanding of the legal culture [20; 15, p. 50-58].

There are other approaches to understanding the legal culture. It defined as a social mechanism that, in accordance with the achieved level of legal conscious- 
ness, provides the production, storage and transfer of legal values, information, traditions that promote lawful and socially active behavior of people; as a process of gradual development of legal reality that is constantly improving; as an expression of the state legal experience of specific social communities and individuals in the material and spiritual processes, products of life, in skills and values that affect at their legally meaningful behavior; as a higher form of legal consciousness; as the legal environment of people, collection of texts legitimated as legal ever, and the mechanism for its creation, storage and broadcasting; as a progressive-valuable part of the actual and legal existence of the legal system $[21$, p. $13 ; 22$, p. $450 ; 23$, p. 188], etc.

Without diminishing the fruitfulness of the approaches to defining the concept of legal culture, we are joining those scholars who adhere to the axiological approach to its interpretation. This approach to explaining the specifics and content of legal culture is the most widespread. The axiological approach to comprehend the culture allows us to combine its various qualities within the notion of value, because values caused from the outside, from the depths of individual and social life that what we call the culture of the people and society. The notion of value firstly was introduced by I. Kant, who opposed some social field of moral freedom and human duties to the natural necessity. I. Kant recognized values as the highest principle of human behavior. The category of values involves two ways for its understanding: externalist and internationalist. Firstly, values are the totality of cultural goods created by human and make up his personal and social wealth (every society has the legitimate system of values that determines the social being of its members). Secondly, the value is also an immanent, inherent in the consciousness of human, intention (lat. intention - aspiration, focus on the subject), that motivates its productive activity. Orientation to values is the main feature of human activity that states the culture and all the concrete forms of its manifestation.

In accordance with the axiological approach, culture, in its essence, represents the objectification of value-world-perceptible representations expressing the inner world of human subjectivity. Therefore, the concept of an axiosphere is authentic to the concept of culture. This means that culture, first of all, acts as an actual value system for the individual and society as a whole. It's considered as a set of values created and developed by mankind during its history [24, p. 41]. From this point of view, the legal culture, in our opinion, is a set of values created by people in the legal field. The same understanding of legal culture reflected in the scientific works of many scholars. For example, V. P. Salnikov notes that «the legal culture of society is presented as a kind of social culture that reflects a certain level of legal awareness and legality, perfection of legislation and legal practice that covers all the values created by people in the law field» [25, p. 575]. Accord- 
ing to S. S. Alekseyev's opinion, «legal culture is a kind of legal wealth that is expressed in the level reached by the development of regulatory qualities of law, by accumulated legal values, by those features of law and legal technology that relate to spiritual culture, to legal progress» [26, p. 149].

Legal values constitute the core of value-normative orientations of legal consciousness and serve as the main factor of socio-cultural integration. In this regard, the study of legal values allows us to obtain the scientific information on the most fundamental aspects of the legal culture of Ukrainian society, and this knowledge, in turn, provides an opportunity to understand the state of the legal life of society [14, p. 148-149]. The great importance in its formation belongs to the legal mentality.

The content of legal mentality reflects the process of law-cultural development that manifests itself both in the way of thinking and in the way of action. It is in its own way unique, specific and inseparable from social mentality. Legal mentality is represented by three types: the first, by internal state of the individual, by changing and symmetric elements of his psyche, and secondly, by subject-subjective and object-objective relations in the legal activity field, and thirdly, by the results of legal relations and activities, that is, by mental legal environment where people and their social communities actually live and work.

It can be distinguished four elements in the structure of legal mentality that reveal its essence and form its integrity. The first component is cognitive that includes the legal worldview and legal consciousness and determines the legal behavior of the individual. The second element is an estimate that reflects how the legal values can be mediated in the minds of the individual and society as a whole. The third - is the communicative component of legal mentality. It is associated with the legal traditions that characterize this type of society. They represents as social experience that accumulates legal values and passed from one generation to another within certain spatial and legal limits. The fourth component is a sensitive element that characterizes human emotions and reflects its legal psychology that encompasses a set of value relationships, moods, desires and experiences that characterize individual or, in general, particular society.

Legal mentality plays an active role in shaping the legal culture. It does not allow transforming the positive right to self-denial, torn from social being legal dogma, because it is spiritual and legal psychological invariant that has conservative forms of reproduction of its inherent values. Due to this, legal mentality acts as the basis that helps society legal culture to provide functionally its own cultural specifics, while legal systems preserve national identity.

The legal mentality preserves and passes to the next generations all valuable in legal culture, allows to borrow the best examples of legal culture of other countries 
and to reject foreign legal ideas, theories, norms of this legal culture [27, p. 271272].

Functions of legal culture take great importance to ensure the functioning of its mental mechanism. Legal culture performs cognitive, regulatory, normative-value, communicative and predictive functions in society. The first function is to assimilate the legal heritage of past epochs and modern achievements of domestic and foreign law. It is tightly connected with the formation of the law state with and development of civil society. The regulatory function of legal culture is aimed at ensuring stable and effective functioning of society by prescribing the standards of socially useful behavior to individuals and social groups. Legal culture ensures the harmonization and conquest of social aspirations and ideals of different groups to the legal requirements of society and thus makes order in public relations. The normative-value function ensures the bringing of legal behavior into line with patterns of behavior, the benchmarks of which are the rules of positive law and normative settings of natural law. As a result of cultural-legal assessment, some elements of legal reality get praise, others get critical comprehension. The communicative function of legal culture contributes to the coherence of social, group and personal interests, ensures social cohesion of people. This function realizes in legal communication, in the process of education, mediated by the media, literature and other types of art. The prognostic function expresses in opportunities to envisage trends in the development of the legal system, law-making and the implementation of law, legal practice, social and legal activity of citizens, etc. These functions in their totality predetermine the system of mental processes underlying the legal culture.

The above mentioned issues suggest that the legal mentality is an unique legal phenomenon that encompasses the style of legal thinking and behavior, legal knowledge and ideas that characterize particular individual and society as a whole, and that determines by individual and social experience. Legal mentality enables the legal culture to preserve its own identity, not dissolve in multiple contacts with other legal cultures. General, human civilization, ethnic, corporate, group and other legal values constitute the «genetic code» of legal mentality that determines the peculiarities of legal consciousness and legal behavior of different nations, nationalities, social groups and individuals. Because of these values the legal mentality forms its own unique spiritual world that allows it to develop its inner essence and axiological meaning. Due to this valuable «genetic code» of legal mentality acts as the nucleus of legal culture.

Conclusion. Social and philosophical analysis of legal culture allows us to substantiate scientifically the advantages of the axiological approach among other theoretical and methodological directions of the consideration of this social 
phenomenon. This approach covers the various qualities of legal culture around the concept of value. Also legal mentality has an axiological characteristic that includes basic ethno genetic values that preserve their own identity of the legal culture and does not allow it to lose its specificity in the process of interaction with other legal cultures. These values of legal mentality are an integral part of the legal culture.

\section{REFERENCES}

1. Backhouse, C. (2017). Contesting the legal culture of professionalism. International Journal of the Legal Profession, 24 (1): 55-59.

2. Blumenthal, S. L. (2016). Law and the modern mind: consciousness and responsibility in American legal culture. Cambridge, Massachusetts: Harvard University Press.

3. Budnik, A. ed. (2015). Locus standi across legal cultures. Białystok: «Temida 2»k.

4. Butko, L., Markhgeym, M., Novikova, A., Pozharova, L. \& Tonkov, E. (2017). Personal Dignity in the European Legal Culture. Journal of History Culture and Art Research, 6 (4): 296-303.

5. Colson, R., Field, S. eds. (2016). EU Criminal Justice and the Challenges of Diversity: Legal Cultures in the Area of Freedom Security and Justice. Cambridge, United Kingdom: Cambridge University Press.

6. Dias, J. P. (2016). The transition to a democratic Portuguese judicial system: (delaying) changes in the legal culture. International Journal of Law in Context, 12 (1): 24-41.

7. Diduck, A., Peleg, N., Reece, H. eds. (2015). Law in society: reflections on children, family, culture and philosophy: essays in honour of Michael Freeman. Leiden, the Netherlands: Brill Nijhoff.

8. Drolshammer, J. (2016). The Americanization of Swiss legal culture: highlights of cultural encounters in an evolving transatlantic history of law. Bern: Stämpfli publishers.

9. Durbach, A., Lixinski, L. eds. (2017). Heritage, culture and rights: challenging legal discourses. Oxford; Portland, Oregon: Hart Publishing.

10. Helleringer, G., Purnhagen, K. eds. (2014). Towards a European legal culture. München: C.H. Beck; Portland, OR: Hart; Baden-Baden: Nomos.

11. Hytonen, J. (2016). The problematic relationship of communicative planning theory and the Finnish legal culture. Planning Theory 2016, 15(3): 223-238.

12. Junker, K. W. (2016). Legal culture in the United States: an introduction. Abingdon, Oxon; New York, NY: Routledge.

13. Lemay-Hérbert, N., Freedman, R. eds. (2017). Hybridity: law, culture and development. Abingdon, Oxon; New York, NY: Routledge.

14. Pravosvidomist i pravova kultura yak bazovi chynnyky derzhavotvorchoho protsesu v Ukraini: monohrafiia / L. M. Herasina, O. H. Danylian, O. P. Dzoban ta in. (2009). Kharkiv: Pravo [in Ukrainian]. 
15. Pravova i politychna kultura ukrainskoho sotsiumu za umov modernizatsii politykopravovoho zhyttia: monohrafiia / O. O. Bezruk, L. M. Herasina, I. V. Holovko ta in.; za red. M. P. Trebina (2016). Kharkiv: Pravo [in Ukrainian].

16. Provost, R. ed. (2017). Culture in the domains of law. Cambridge, United Kingdom: Cambridge University Press.

17. Sharp, C., Leiboff, M. eds. (2016). Cultural legal studies: law's popular cultures and the metamorphosis of law. Abingdon, Oxon; New York, NY: Routledge.

18. Šarčević, S. ed. (2015). Language and culture in EU law: multidisciplinary perspectives. Farnham, Surrey, England; Burlington, VT: Ashgate.

19. Zellentin, H. M. (2013). The Qur'an's Legal Culture: The Didascalia Apostolorum as a Point of Departure. Tübingen: Mohr Siebeck.

20. Klimova, H. P. (2013). Do pytannia pro sutnist pravovoi kultury. Visnyk Natsionalnoho universytetu "Iurydychna akademiia Ukrainy imeni Yaroslava Mudroho». Seriia: Filosofiia, filosofiia prava, politolohiia, sotsiolohiia. Issue 3, 180-182 [in Ukrainian].

21. Ionnikov, I. A. (1998). Kontseptsiya pravovoy kulturyi. Pravovedenie, 3, 11-22 [in Russian].

22. Polyakov, A. V. (2003). Obschaya teoriya prava: Fenomenologo-kommunikativnyiy podhod: Kurs lektsiy. 2-e izd., ucheb. SPb.: Yuridicheskiy tsentr Press [in Russian].

23. Petrov, A. V., Simkanich, O. M. (2009). Pravovaya kultura: soderzhanie i formyi suschestvovaniya. Vestnik Nizhegorodskogo universiteta im. N. I. Lobachevskogo. Seriya: Pravo, 2, 186-193 [in Russian].

24. Pravova kultura - osnova derzhavotvorennia v Ukraini: zb. nauk. prats. Vyp.1 / red. M. V. Kostytskyi (2005). Irpin: Natsionalna akad. DPS Ukrainy [in Ukrainian].

25. Teoriya gosudarstva i prava. Kurs lektsiy / Pod red Matuzova N. I., Malko A. V. (2001). 2-e izd., pererab. i dop. Moskva: Yurist' [in Russian].

26. Alekseev, S. S. (2009). Obschaya teoriya prava. Moskva: Prospekt [in Russian].

27. Klimova, H. P. (2017). Pravova mentalnist yak yadro pravovoi kultury. Visnyk Natsionalnoho universytetu «Iurydychna akademiia Ukrainy imeni Yaroslava Mudroho». Seriia: Filosofiia, filosofiia prava, politolohiia, sotsiolohiia. Issue 2, 270-273 [in Ukrainian].

\title{
ПРАВОВАЯ МЕНТАЛЬНОСТЬ И ПРАВОВАЯ КУЛЬТУРА: ПРОБЛЕМЫ ВЗАИМОДЕЙСТВИЯ
}

\author{
Климова Г. П.
}

В статье представлены основные теоретико-методологические подходы к анализу сущзности правовой культуры. Особое внимание уделено раскрытию специифики аксиологического контекста данного соииального феномена. Рассмотрена сущность и структура правовой ментальности. Проанализировано соотношение правовой ментальности и правовой культуры. 
Ключевые слова: культура, правовая культура, правовые иүенности, функции правовой культуры, ментальность, правовая ментальность.

\title{
ПРАВОВА МЕНТАЛЬНІСТЬ І ПРАВОВА КУЛЬТУРА: ПРОБЛЕМИ ВЗАЕМОДІЇ
}

\author{
Клімова Г.П.
}

У статті представлені основні теоретико-методологічні підходи до аналізу сутності правової культури. Особливу увагу приділено розкриттю специифіки аксіологічного контексту даного сочіального феномену.

Поняття правової культури - багатогранне, багатоаспектне. Тому для його аналізу використовуються різноманітні теоретико-методологічні підходи. Серед них: суб 'єктивний, діяльнісний, антропологічний, технологічний, якісний, соціологічний, аксіологічний та ін.

Так, відповідно до суб' сктивного підходу під правовою культурою розуміється певний ступінь знання законодавства та поваги до норм права. Це дуже звужує поняття правової культури. За його межами опиняються такі суттєві явища, як правовий статус особистості, правова поведінка та ін. Насправді поза правовою культурою опиняються і самі правові норми, оскільки мова йде не про ці норми, а лиме про ставлення до них. Послідовна реалізація зазначеного підходу при аналізі правової дійсності приводить до ототожнення правової культури з правосвідомістю.

У відповідності до діяльнісного підходу правова культура розглядається як правотворча діяльність. Цим саме з правової культури виключаються інші, до того ж в не меншій мірі важливі, види юридичної діяльності, наприклад, правозастосовча діяльність, або діяльність громадян з підвищення свого правоосвітнього рівня тощо. 3 правової культури випадає уся репродукиійна, відтворююча діяльність.

Антропологічне розуміння правової культури виходить з того, щуо культура охоплює все, щуо відрізняє життєдіяльність людини і суспільства від природи, щуо існує, тобто всі боки людського буття. Виходячи з изього широкого розуміння культури, в науковій літературі можна зустріти досить широкі визначення правової культури. Зразком може бути розуміння правової культури як системи матеріалізованих та ідеальних елементів, щуо належать до сфери дї̈ права і їх відбиття у свідомості й поводженні людей.

Існують й інші підходи до розуміння правової культури. Її визначають як соціальний механізм, за допомогою якого забезпечуються у відповідності з досягнутим рівнем правової свідомості виробництво, зберігання і передача правових иінностей, інформаиії, традицій, щзо допомагають правомірній і соиіально активній поведіниі людей; як прочес поступового розвитку правової дійсності, який постійно вдосконалюється; як вираження державного правового досвіду конкретних соціальних спільнот і індивідів в матеріальних і духовних проиесах, продуктах життєдіяльності, в навичках і иінностях, які впливають на їх юридично значиму поведінку; як більи високу й містку форму правосвідомості; як правове середовище людей, сукупність 
текстів, будь-коли легітимованих як правових, і механізм з їх створення, зберігання і трансляиї; як прогресивно-иіннісну частину актуального і юридичного буття правової системи.

Не принижуючи плідності підходів до визначення поняття правової культури, що були наведені, ми приєднуємося до тих вчених, котрі дотримуються аксіологічного підходу до його трактовки. Даний підхід до пояснення специфіки і змісту правової культури є найбільш розповсюдженим. Аксіологічний підхід до осмислення культури дозволяє об 'єднати ії різноманітні якості навколо поняття иінності, оскільки иінності і обумовлюють ззовні, з глибин індивідуального і соиіального життя те, щуо ми називаємо культурою народу і суспільства. Найважливіше значення в їх формуванні належить правовій ментальності.

Зміст правової ментальності відображає процес правокультурного розвитку, щзо проявляється як в характері мислення, так і в образі дії. Він по-своєму унікальний. Це специфрічний і невіддільний від соиіальної ментальності.

Правова ментальність грає активну роль у формуванні правової культури. Вона не дає трансформувати позитивне право в самодостатню, відірвану від соиіального буття мляву юридичну догму, оскільки являє собою духовно-правову психологічну інваріанту, яка має консервативні форми відтворення властивих ій иінностей. $3 а-$ вдяки иьому правова ментальність виступає тим стрижнем, за допомогою якого правова культура суспільства функиіонально забезпечує власну культурну специфіку, а правові системи зберігають національну ідентичність.

Правова ментальність зберігає і передає наступним поколінням все цінне в правовій культурі, дозволяе запозичувати кращі зразки правової культури інших крайн і відторгати чужі даній правовій культурі правові ідеї, теорії, норми.

Найважливіше значення для забезпечення дії ментального механізму правової культури мають ї̈ функиії. Правова культура виконує в суспільстві пізнавальну, регулятивну, нормативно-циіннісну, комунікативну і прогностичну функції.

Правова ментальність дає можливість правовій культурі зберегти свою власну ідентичність, не розчиниться у множинних зіткненнях з іншими правовими культурами. Загальнолюдські, загальночивілізачійні, етнічні, корпоративні, групові та інші правові иінності складають «генетичний код» правової ментальності, який обумовлює особливості правової свідомості та правової поведінки різних націй, народностей, соиіальних груп і окремих індивідів. Через иі иінності правова ментальність формуе свій власний неповторний духовний світ, що дозволяе їй розвинути свою внутрішню сутність і аксіологічний зміст. Завдяки цььому иіннісний «генетичний код» правової ментальності виступає ядром правової культури.

Ключові слова: культура, правова культура, правові цінності, функиї̈ правової культури, ментальність, правова ментальність.

\section{$\operatorname{soc}$}

